I was born in 1921 and in my early years I spent a lot of time in the nearby river breaks, never seeing or hearing of foxes in the wild. In 1930, a neighbour $1 / 2$ mile south of our farm, started a fox farm with silver foxes and an occasional red fox brought in for crossbreeding to supposedly improve the silver colouring. A good silver fox was black with a generous sprinkling of white hairs over the black and a large white tip on the tail. Many of the progeny were a slate blue-black colour, and so, not a very valuable pelt.

There were reports of a fox escaping once in awhile, but I never saw any and at that time most farmers or their sons ran a trapline for coyotes, so an escaped fox would have a difficult time to survive. The fox farm enterprise came to a sudden end in 1941. During the 1950s a local man, now deceased, told me that he had been trapping foxes in the Kyle area, I assumed that it was north of Kyle.

My first contact with a wild Red Fox came on 17 November 1966 when it ran onto the road in front of my truck, 2 miles north of my present farm. The snow was perhaps 10" deep and the fox chose to stay on the hard track. I showed down to give it a chance to get off, but it would not, so deciding this was a good chance to destroy it, as I raised poultry, I stepped on the gas and drove over it, stopping immediately and picking it up. It was killed instantly and I found it was a female, weighing 10 pounds and measuring 44 " in length.

During the 1970 s and 1980s foxes became quite plentiful and I remember counting dens beside the road, from my farm in Kyle, a distance of 17 miles. No doubt there were many more that I was not aware of.
During the last few years we have been seeing foxes that are infected with mange and are not as plentiful in this area. During the 1920s and 1930s and into the 1940s there was an abundance of jackrabbits, then in the late 1950s and 1960s a great decline and I wonder if this is not due to the high population of foxes capturing the young rabbits.

- Sig Jordheim, Box 544, Kyle, SK. SOL 1 T0

\section{TURKEY VULTURES TO HUMMINGBIRDS: BIODIVERSITY AT SPARC}

With 1995, came the 75th anniversary celebration of the Semiarid Prairie Agricultural Research Centre (SPARC), formerly known as the Swift Current Research Station. The number "75" was spelled out in white petunias against a red floral background in the "Horseshoe Garden," a well-known local landmark. The 4th of July festivities were honoured by the presence of Agriculture Minister Ralph Goodale. As the spouse of the current director and an avid birder, I wish to advertise another reason why this piece of government land should be cause for celebration.

I have had the privilege and pleasure to live on the Centre's grounds for the past year. The landscape that surrounds our house and nearby buildings resembles a lush oasis in the heart of pastures and cultivated fields. This is the result of a gradual change from semiarid grassland, 75 years ago, to a mixed region of park and prairie.

This concentration of greenery is also a magnet for birdlife, with an amazing richness of species diversity. I have counted 157 bird species to date, including 17 sparrows, 24 warblers and vireos and six types of 
thrush. Migration months have brought frequent surprise visitors. The Varied Thrush and Cape May Warbler both appeared briefly on 12 May 1995, a Black-throated Blue Warbler on 25 October 1994 and a Black-headed Grosbeak on $30 \mathrm{Au}$ gust 1995 stayed for several days during the fall. Even in the heart of summer, flocks of Red Crossbills and White-winged Crossbills took up residence in the spruce tops.

The Director's House serves as a wildlife blind and I have observed many birds foraging, unaware of my presence, as I peek out through windows. On the morning of 27 May 1995 I observed a male Mourning Warbler in his striking breeding plumage, just metres from the house, gleaning the garden for insects. A Lazuli Bunting on 12 June 1995 and a Solitary Vireo on 14 June 1995 were two birds whose spring songs led me to their whereabouts. The rarest bird I have seen here was a Barn Owl on 26 November 1994. However, without photographic evidence it is difficult to reinforce the validity of this sighting.

In addition to the cultivated land, pasture-land and irrigation ditches one would expect to find at an Agricultural Centre, the property offers a variety of other habitats for both breeding and transient birds. Within the 925 hectares, sloughs, remnant native prairie, a canopy of elms, spruce and lodgepole pines and an understorey of honeysuckle and berry shrubs supply generous food and shelter. From the cool shade of mature trees to the dry wind of open grassland, the dainty Ovenbird is replaced by the invisible Sprague's Pipit.

High biodiversity or "species density" within a community is often an indication of its richness and structural complexity. From my birder's perspective, the changes that have taken place since the Centre was established appear to be an enhancement for this area. In reality, the luxuriant growth of the Centre's wooded park is an artificial situation, maintained over the years through inputs of water and labour. Not a sustainable system - if left to fend for itself in semiarid Swift Current, the vegetation would begin to die off after several years of drought.

Nature Saskatchewan literature provides us with the alarming statistic that the province has lost $75 \%$ of its native mixed-grass prairie in the past 100 years. In 1921 this was also the land that was broken for experimental work. As I enjoy the results many years later, a question concerns me - is this really enhancement? Does quantity (157 species) outweigh quality? - the sacrifice of open space that could have been home to now endangered prairie species?

The Research Centre represents another example of the transformation of prairie habitat under the pressure of human development. In this case, however, the SPARC grounds may be considered environmentally friendly - as beneficial as the sheltering foliage found in coulee stands across the prairie. As a quasi Point Pelee of southwestern Saskatchewan, the varied habitats within the SPARC property offer valuable refuge to many birds on their migration route, just as Swift Current is an important stopover for human travellers.

The complete list of SPARC bird species many be obtained by writing to the author. I have also compiled a data base of daily recorded sightings of bird species in Swift Current as 
the beginning of a seasonal abundance checklist for this area.

- Laure W. Neish, P.O. Box 1937, Swift Current, SK. S9H 4M6

\section{PEREGRINE VERSUS YELLOWLEGS}

Galloway Bay which is located 10 miles west of White Bear was at one time farmland and some still is. When Lake Diefenbaker is full to capacity, many acres are flooded with shallow water, making it a popular gathering place for ducks, geese, cranes, shorebirds and also birds of prey.

On 30 September 1995 I was parked at the shore of Galloway Bay viewing the hundreds of thousands of birds when I noted three Greater Yellowlegs feeding at the right of my vehicle. Suddenly these birds gave a cry of alarm and flew across the water directly in front of me. Down plummeted a Peregrine Falcon. Just when I expected to see feathers fly as the falcon was about to make contact with one of the yellowlegs, there was a splash and the peregrine zoomed upwards. The yellowlegs appeared again, almost immediately, and started flying. The falcon swooped and again at the right split second there was a splash of water and the falcon soared upward. Again the yellowlegs appeared above the water and commenced flying, and down came the falcon. This time I concentrated on the yellowlegs rather than the falcon as I wondered if it actually went underwater, and I saw that it was completely submerged.

This time a passing small bird, either a Horned Lark or Lapland Longspur got the attention of the peregrine and he gave it pursuit so the yellowlegs flew off to safety. The small bird managed to out manoeuvre the falcon.

- Sig Jordheim, Box 544, Kyle, SK. SOL 1T0

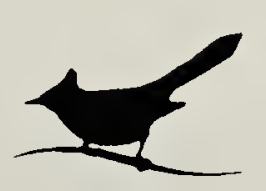

About the orchids of that place [rain forest] we knew very little. About flies and beetles almost nothing, fungi nothing, most kinds of organisms nothing. Five thousand kinds of bacteria might be found in a pinch of soil, and about them we knew absolutely nothing. This was wilderness in the sixteenth-century sense, as it might have formed in the minds of the Portuguese explorers, its interior still largely unexplored and filled with strange, myth-engendering plants and animals. From such a place the pious naturalist would send long respectful letters to royal patrons about the wonders of the new world as testament to the glory of God. And I thought: there is still time to see this land in such a manner. Wilson, E.O. 1992. The diversity of life. W.W. Norton and Company, New York. 424 pp. 